\title{
Strategies and Challenges for the Circular Economy: a Case Study in Portugal and a Panorama for Brazil
}

\author{
Fábio Ribeiro de Oliveira ${ }^{1 *}$ \\ https://orcid.org/0000-0002-2783-0157
}

Rui Ferreira dos Santos ${ }^{2}$

https://orcid.org/0000-0003-2829-6475

\section{Sergio Luiz Braga França ${ }^{3}$}

https://orcid.org/0000-0003-1783-3167

\section{Luís Alberto Duncan Rangel ${ }^{3}$}

https://orcid.org/0000-0003-1431-9859

\begin{abstract}
${ }^{1}$ Federal University of Bahia, Department of Environmental Engineering, Salvador, Bahia, Brazil. ${ }^{2}$ NOVA University Lisbon, NOVA School of Science and Technology, CENSE - Center for Environmental and Sustainability Research, Caparica, Portugal. ${ }^{3}$ Fluminense Federal University, Engineering School, Sustainable Management Systems, Niterói, Rio de Janeiro, Brazil.
\end{abstract}

Received: 2018.11.13; Accepted: 2020.02.13.

${ }^{*}$ Correspondence: fabio.ribeiro@ufba.br; Tel.: 55-71-3283-9780 for FRO

\section{HIGHLIGHTS}

- Circularity actions in Portugal involve the articulation and engagement of stakeholders.

- There is a lack of indicators to measure the performance of the in-progress circularity actions.

- Circular economy strategies need to be aligned with international market constraints.

- International benchmarking can contribute to a national circular economy plan in Brazil.

\begin{abstract}
This article is about a case study based on the participation and contact with dynamized activities through action plans for the circular economy in Europe, specifically in Portugal. It aims to identify the main in-progress actions and the challenges for the diffusion of the circular economy in the Portuguese nation and draw a panorama for Brazil, transiting through different data sources, economic sectors and stakeholders. Through data triangulation, the investigative plan contemplated participatory observations in workshops, interviews with experts, documental analyses and means of communication. After going through data cross checking for validation, the content was aggregated to a strategic analysis matrix. As a result, it was possible to identify the strengths, weaknesses, opportunities and challenges associated with the growth of the circular economy in Portugal, as well as to indicate directions and possibilities in the Brazilian context. It is possible to realize, for both countries, the importance of the international benchmarking for the recognition and promotion of circular economy actions, besides the necessity to revise laws aligned with the internal e external market rules, by increasing the offer of circular products and services.
\end{abstract}

Keywords: Circular economy; Sustainability; Environmental governance; Benchmarking; Strategic planning; European Union 


\section{INTRODUCTION}

The transition to a Circular Economy (CE) has recently gained space in the European political goals through the Roadmap to a Resource Efficient Europe, with efforts towards a society that adopts measures related to forms of efficiency, recuperation and recycling, having 2020 as the goal $[1,2,3]$. Such reference served as basis for the formulation of a Circular Economy Package, which later culminate with the European Union (EU) Action Plan for the Circular Economy - Closing the Loop [3,4]. Thus, the EU establishes initiatives based on the life cycle ideals and concrete goals for residue management [5], seeking competitiveness and an economic scenario aligned with the sustainability ideals [4].

The changing field for a CE requires an expansion of the knowledge bases and better analytical structures [6],comprehending, among others, how the transition happens in face of the barriers from the linear institutional systems [7], providing an alignment of new rules with the CE principles and practices [8]. Thus, a further deepening into the challenges for the CE on a national level that identifies opportunities and recognizes actions correlated to the theme is necessary. Besides the general orientations and commitments stipulated for the Member States, the EU Action Plan also encourages national conformity, with the structuring of proposals and execution of programs according to the particularities of each country [4].

In face of the exposed facts, the goal of this study is to identify and analyze, based on the main inprogress actions, the strategies and challenges of a transition to the CE in Portugal. From such diagnosis, it is intended to discuss how the experience in a European country can generate perceptions for the promotion of the CE in Brazil, in face of the identification of the current panorama. There is a lack of Brazilian studies with such approach [9]. The importance of exploratory researches founded on the knowledge exchange between Portugal and Brazil happens because of the historical and cultural ties between both countries.

\section{The Circular Economy and In-Progress Actions in Portugal}

The CE aims to keep products, components and materials at their highest utility and value within the system [10], being restorative and regenerative by principle [11], having as transition basis the probing of new business models and design strategies [12,13], which include projects for a longer life cycle, maintenance, repairing, reuse, remanufacturing, remodeling and recycling of materials and energy [14].

Constituted in 2010, with the intention of speeding the transition to a CE, the Ellen MacArthur Foundation - EMF works along with companies, governments and educational and research centers with this goal and, for this purpose, points out three principles for a CE system [11]:

1 - To preserve and improve the natural capital, by controlling finite stocks and balancing the renewable resource flows.

2 - To optimize the efficiency of resources, making components, products and materials at the highest level of utility circulate, in the technical as also in the biological cycles.

3 - To stimulate the effectiveness of the system by revealing and excluding the negative externalities from the beginning.

The CE represents the generation of opportunities in the productive chains [15], with the development of products and business models that can adjust better to the natural cycles, enabling the minimization of negative externalities [16]. In face of the necessity for new production and consumption models, the discussions about the CE have strengthened in the international scenario, but the countries that have taken concrete measures for its implementation are still few [7]. The main CE in-progress actions in Portugal related to the case study performed between the months of April and July of 2017 , which were identified through documents and events related to the $\mathrm{CE}$, are listed as follows.

\section{Documents and Guiding Media}

\section{i- The European Union Action Plan for the Circular Economy [4]}

As it was cited in Introduction, the document "The European Union Action Plan for the Circular Economy - Closing the Loop", launched in December, 2015 by the European Commission, presented a package of measures that seeks the transition to the $C E$. Such measures range from the revision of residues legislation to the strategic lines of action, and are focused on innovation, investment and new production and consumption models, in each stage of the value chain.

ii - Science and Technology National Plan, 2017-2020: Investigative agenda for circular economy [17] 
The document is composed by 14 thematic and strategic agendas for the country, among them, the CE. Structured as an opportunity for the enhancement of sustainability, resilience, social inclusion and competitiveness, the agenda for the CE in Portugal represents a big challenge for the investigative and innovation strategies, seeing that besides technological solutions, behavior changes in society are necessary as well. For such, it highlights the importance of the active participation of all the actors of the value chain in a systemic, multidisciplinary and collaborative way, by seeking the coordinated conception of solutions to the transition process.

The agenda, still in the consolidation phase of the initial discussion terms, relies on four motivational pillars for the development of the investigation and innovation: design and development of new products; processes and services; sustainable management of resource cycles; governance and territory; new business, behavior and consumption models.

iii - Action Plan For The Circular Economy in Portugal

It is an effort from the Inter-ministerial Group for Circular Economy (IGCE), with the participation of four ministries: Environment; Economy; Agriculture, Forestry and Rural Development; Science, Technology and Higher Education. It proposes that Portugal should lead the transition to a CE, aimed at concrete proposals that reach public institutions, companies and community in their actions and behaviors [18].

The preparation for the plan went through a national framework, analysis and international benchmarking (Holland and Finland), having the European Union Action Plan for the Circular Economy as a model, with central actions around the following fundamental pillars: Product; Consumption; Knowledge; Residues and secondary raw materials [18]. The implementation passes through a political commitment, in a way to be integrated into the ambit of the Interministerial Commission for Air and Climate Changes (ICACC) through a commission of representatives of ministries, directive committees and technical groups.

iv - ECO.NOMIA Portal - www.eco.nomia.pt

A portal that became available from September 2016, with the mission to dynamize CE actions and enable the interaction for the development of new projects. It gathers a lot of information linked to the circularity in the economy, such as concepts, strategies, policies, documents, financing opportunities, events and successful cases in diverse sectors, mostly from Portugal [19].

\section{$v-B C D S$ Portal Portugal - www.bcsdportugal.org}

The Business Council for Sustainable Development (BCDS Portugal) was founded in October 2011 and has about 80 members, encompassing important companies in the economy of Portugal. It is a non-profitable association aimed at the aggregation and representation of companies committed with sustainability, acting through projects related to new intercompany business models guided by the sustainable development goals [20].

\section{Workshops and Meetings}

i- Workshop: The Circular Economy in the Achievement of Sustainable Development Goals. Lisbon. Ismaili Centre, 05/25/2017.

The event was held during the 12th Social Responsibility Week organized by the Portuguese Association for Business Ethics and the United Nations Global Compact Network Portugal. The workshop, co-organized by the "Águas de Portugal" Group, gathered representatives of education and investigation centers, companies, public organisms and civil society to discuss the CE in the ambit of sustainability and business, specifically in the achievement of the sustainable development goals.

ii - 1st National Workshop of the KATCH_e Project; Design for the Circular Economy. Aveiro, University of Aveiro, 06/09/2017

The KATCH_e project refers to Knowledge Alliance on Product-Service Development towards circular economy and sustainability in higher education. It is supported by the Erasmus+ program, which aggregates, besides Portugal, partners in Spain, Austria and Denmark. It has the development of products and productservice systems for the $\mathrm{CE}$ and the sustainability in the furniture and construction sectors as its main line of work.

The first workshop on the project had the participation of associations, higher educational institutions and national companies. Its goal was the identification and analysis of formation necessities, the state of art, 
existing trends and policies of the CE in Portugal. The focuses of discussion were the challenges, products and services for the CE in the furniture and construction sectors, besides the skill requirements and the qualification for the design and development teams.

iii- ECO.BIO Workshop - Agriculture and Forestry in the Circular Economy Context. Lisbon, Water Museum, $06 / 21 / 2017$

The ECO.BIO conference was the third workshop in a cycle supported by the Ministry of Environment and other stakeholders to promote and dynamize the transition to the CE. The two previous meetings approached the CE as a competitive advantage for medium-sized and small companies (ECO.PME) and the financial system challenge of supporting the transition to circular systems (ECO.FINANCIA).

The goal of ECO.BIO was to discuss the application of the CE in the agriculture and forestry sectors, besides the introduction of the Action Plan for the Circular Economy in Portugal. It had the participation of the Ministry of Environment, experts, startups, business incubators, public institutions and educational and research centers.

iv - Meeting with Science and Technology in Portugal - Session about Circular Economy. Lisbon, Congress Centre, 07/05/2017

Science 2017, in its fifth edition, was organized by the Science and Technology Foundation in collaboration with Live Science - National Agency for Scientific and Technological Culture and the Parliamentary Committee for Education and Science, with the support from the Ministry of Science, Technology and Higher Studies. Its goal was the promotion and debate about the main themes and challenges of the agendas for the Science and Technology National Plan 2017-2020, open to the whole society. The CE had a session focused on: research on bio-refineries; atmospheric emissions reduction measures and solid wastes recovery; and presentation and discussion of the challenges for the agenda.

\section{MATERIAL AND METHODS}

Taking into consideration the goals that guide this research and the necessity for immersion in the study context, a case study of qualitative nature, according to the investigative plan in Table 1, where the instruments, techniques, samples and research focus are presented, was performed.

For the identification of the CE in-progress actions in Portugal, the research strategy used data triangulation, in which three methods to investigate the same goal of the study were used [21]. The use of triangulation provides a better quality for the case study research [22,23],contributing to the data validation [24,25].

Four basic types of data collection are highlighted in a qualitative research: observations (in a participative way or not); interviews; documents (public or private); and audio and visual materials [26]. Thus, an analysis of documents and visual communication materials, for public disclosure, focused on sharing knowledge, seeking interaction among the stakeholders and proposing action and investigative strategies for the CE was performed in first place.

In addition, the participative observation in workshops and meetings aimed at discussions about the CE in the diverse sectors of the Portuguese economy, previously presented, besides the recognition of actions, the diagnosis of challenges and potentialities in the internal and external scenarios for Portugal. Such events also provided the interaction with stakeholders through semi-structured interviews, composed by questions that addressed the identification of strengths, weaknesses, opportunities and threats for the dynamization of the CE in the country, previously captured in the early phases of the research.

The information collected in the documentary research, participative observation and semi-structured interviews, after going through data cross checking for validation, had the content aggregated according to the composition of a SWOT matrix, with reference to Strengths, Weaknesses, Opportunities and Threats. The SWOT analysis has been used in many fields related to decision-making processes and strategic analyses [27], enabling to recognize and compare strong/weak points and opportunities/threats, resulting from the internal and external factors related to the object of study.

Supporting the reflection on how the experience in Portugal can be used as a basis for a wider promotion of the CE in Brazil, articles included in the Scopus database until December/2017, with the search terms "Brazil" and "Circular economy" in the titles, summaries and key words, were considered. The studies entitled "Economia circular Holanda - Brasil: da teoria à prática" (Holand-Brazil circular economy - from theory to practice) [28] and A circular economy in Brazil: an initial exploration [11], were also referred to. 
Table 1 Investigative plan

\begin{tabular}{|c|c|c|c|}
\hline Instrument & Technique & Sample & Focus \\
\hline \multirow{5}{*}{$\begin{array}{l}1- \\
\text { Documentary } \\
\text { research - } \\
\text { identification of } \\
\text { the in-progress } \\
\text { actions }\end{array}$} & \multirow{5}{*}{$\begin{array}{c}\text { Analysis of } \\
\text { documents and } \\
\text { visual } \\
\text { communication } \\
\text { materials }\end{array}$} & $\begin{array}{l}\text { European Union Action Plan } \\
\text { for the Circular Economy }\end{array}$ & $\begin{array}{l}\text { Legislative proposals } \\
\text { and strategic lines }\end{array}$ \\
\hline & & $\begin{array}{l}\text { Science and Technology } \\
\text { National Plan Investigative } \\
\text { agenda for circular economy }\end{array}$ & $\begin{array}{l}\text { Pillars for the } \\
\text { investigation and } \\
\text { innovation }\end{array}$ \\
\hline & & $\begin{array}{l}\text { Action plan for the CE in } \\
\text { Portugal: } 2017-2020\end{array}$ & $\begin{array}{l}\text { Strategic lines for } \\
\text { actions and } \\
\text { investments }\end{array}$ \\
\hline & & ECO.NOMIA Portal & Knowledge sharing \\
\hline & & BCSD Portal - Portugal & Energy enhancement \\
\hline \multirow{4}{*}{$\begin{array}{l}\text { 2- Workshops } \\
\text { and } \\
\text { meetings - } \\
\text { identification of } \\
\text { in-progress } \\
\text { actions } \\
\text { and challenges }\end{array}$} & \multirow{4}{*}{$\begin{array}{l}\text { Participative } \\
\text { observation }\end{array}$} & $\begin{array}{l}\text { Workshop - CE in the } \\
\text { achievement of the sustainable } \\
\text { development goals }\end{array}$ & $\begin{array}{c}\text { Water; } \\
\text { Effluents; } \\
\text { Solid wastes }\end{array}$ \\
\hline & & $\begin{array}{l}\text { National Workshop of the } \\
\text { KATCH_e Project; Design for } \\
\text { the CE }\end{array}$ & $\begin{array}{l}\text { Education; Design; } \\
\text { Furniture; } \\
\text { Construction }\end{array}$ \\
\hline & & $\begin{array}{l}\text { ECO.BIO Workshop - } \\
\text { Agriculture and forestry in the } \\
\text { CE context }\end{array}$ & $\begin{array}{l}\text { Agriculture; Forestry; } \\
\text { National policies }\end{array}$ \\
\hline & & $\begin{array}{l}\text { Meeting with science and } \\
\text { technology in Portugal - } \\
\text { Session about CE }\end{array}$ & $\begin{array}{l}\text { Bio-refineries; } \\
\text { Atmospheric } \\
\text { emissions; } \\
\text { Solid wastes }\end{array}$ \\
\hline \multirow{3}{*}{$\begin{array}{l}\text { 3- Interaction } \\
\text { with } \\
\text { stakeholders: } \\
\text { identification of } \\
\text { challenges }\end{array}$} & \multirow{3}{*}{$\begin{array}{l}\text { Semi-structured } \\
\text { interviews }\end{array}$} & $\begin{array}{l}2 \text { representatives of } \\
\text { association of } \\
\text { companies }\end{array}$ & Furniture \\
\hline & & $\begin{array}{l}2 \text { academic } \\
\text { Representatives }\end{array}$ & Design; Furniture \\
\hline & & $\begin{array}{l}2 \text { representatives } \\
\text { of companies }\end{array}$ & Sanitation \\
\hline
\end{tabular}

\section{RESULTS AND DISCUSSION}

\section{Strengths, Weaknesses, Opportunities and Threats in the Dynamization of the CE in Portugal}

The strengths and weaknesses are consistent with the internal aspects related to the dynamization of the CE in Portugal, and the opportunities and threats are associated with the external aspects that also involve other countries. The main results pointed out in the research and the source of data collection are compiled in the SWOT matrix (Figure 1).

Regarding the strengths, in face of a society that has become more and more dynamic and computerized, consequently resulting in more ephemeral cities, many actions related to the CE have already been accomplished and recognized. In the food production and consumption sector, some examples are: the Cool Farm tool [18], aimed at a high-tech and computerized modular agriculture; Fruta Feia Cooperative, which redirects fruits and vegetables that would be wasted; and the projects PROVE - "promover e vender" (promoting and selling), Cabaz do Peixe and Biovivos. They focus on the approach between producer and 
consumer and are also aligned with the principles of a social and solidary economy, aggregated to the urban and communitarian agriculture [29]. Such practices are important because of the reduction of resources availability and the productive potential in some areas, due to the unsustainable way of exploitation population growth $[30,31]$. The identification and encouragement of transforming actions is fundamental for the incentive of new fronts that can propagate the circularity concepts in the economy.

The Action Plan for the Circular Economy in Portugal [18] is seen as the main proponent for a movement that encompasses from the articulation of ministries to an extensive promotion and discussion with society, workshops and diverse types of meetings, seeking an engagement between the public power, educational institutions and society. It includes national actions of transversal nature, related to ministerial activities, sectorial agendas - mainly in the most intensive sectors in the resources use and exportation; and local agendas, to be adapted to the socio-economic specificities of each region [19]. Some instruments available for the promotion and achievement of the actions are: the circular agreements that identify and overcome barriers to the CE; the alignment of environmental criteria in the operational programs in Portugal; and the approach to the necessity of monitoring indicators [18].

At this point, one of the main weaknesses found is related to the lack of indicators for measuring the circularity in an economy and the performance of the in-progress actions, considering mainly the diversities and complexities of a nation. Such efforts for the formulation of indicators have become the target of recent CE researches, but still with sectoral focuses from case studies [32,33,34,35].

By recognizing such need, the action plan for the CE in Portugal suggests that it is possible to provide a description of the metabolism of the economy, it means, to delineate the evolution in the extraction and productivity of resources, consumption, recycling performance, residual generation [18]. However, such description would only bring a general and preliminary diagnosis, not considering the dimension of factors related to a circular system, like business models, value chain, life cycle of the product, among others.

The main source of discussion about the weakness of a CE system is related to the paradigms, concepts and behaviors established in the society, and the difficulties companies present when idealizing and incorporating such premises internally. The transition to the CE comes from the involvement of all the actors of the society and their capacity of interaction, creating adequate collaboration and exchange patterns [7].

However, the semi-structured interviews also pointed out that many micro, small and medium-sized companies (SMEs) already have circular systems by essence, showing the necessity for a recognition and better structuration of this system. The European policies needs to protect the preferences of consumers, the market value chains and the entrepreneurial cultures, besides the recognition of the circular business models and SMEs [36].

The traditional production systems, with little opening to partnerships and promotion of the productive needs associated with the buying and selling of inputs and byproducts, fit the barriers in which the information exchange is seen as a restriction to the success of the CE initiatives [37]. In general, there is still a lack of online platforms and computerized systems for the operationalization of these practices. It is also highlighted a bigger necessity for sectoral approach to the life cycle of products and encouragement of actions aimed at the flow of products and residues for reuse, like the reverse logistics.

If, on the one hand, the revisions of solid waste legislation have become stronger [19], other points of view highlight that there are still legal requirement problems that stimulate or even provide industrial symbiosis practices. One example is the restrictions to the parameters for the reuse of treated liquid effluents, according to the facts pointed out by the representatives sanitation concessionaire during the interviews.

Regarding the external factors, the main opportunities are related to the adoption of the CE in the European ambit, especially with the EU action plan for the circular economy [4], with guidelines aimed to stimulate the transition of the European companies and consumers to a system in which the resources are used in a more sustainable way [38], being it an important stimulus for the gradual incorporation of the CE concept [39]. On the other hand, the aforementioned Plan may not guarantee the sustainable results due to the fact that it neglects energy, waste and pollution problems, as well as the impossibility of closing the material flow cycles totally [40]. Such position demonstrates the need for deepening into the national particularities towards diagnoses and actions aimed at the CE.

As financial support, there are European programs aimed at the destination of resources from prizes, funds and financings, like the Horizon Program 2020, which contributed 77 billion of Euros to research and development (R\&D) between 2014 and 2020 [41]. It is estimated that the CE and the technological revolution will enable an annual increase of resource productivity of up to $3 \%$ for the economies in Europe, which would signify 0,6 trillion of Euros per year until 2030 [42]. 


\section{STRENTGHS}

Articulation of ministries to promote the CE (D, W)

Assembling of strategic work groups for the promotion of the CE $(D, W)$

Regional agendas and national action plan for the CE $(D, W)$

Promotion of the $\mathrm{CE}$ through workshops, conferences and virtual portals (D, W, I)

Contests of ideas for the circularity (W, I)

Relationship-strengthening initiatives with the consumer (W, I)

Diverse projects and in-progress internal experiences $(D, W, I)$

Engagement of the public power, educational institutions and society (D, W, I)

More dynamic societies and ephemeral cities (W, I)

Online platforms for collective financing (D, I)

Revisions of legislation regarding residues $(\mathrm{D}, \mathrm{W})$

\section{WEAKNESSES}

Paradigms, concepts and behaviors established in society (D, W, I)

Little promotion of entrepreneurial necessities and production information (W, I)

Traditional production systems with restrict opening and cooperation (W, I)

Little stimulus to the systematic view of the workers (W, I)

Few projects suitable for family-owned companies and SMEs (W, I)

Legal requirements frequently disarranged for the promotion of $C E$ practices $(W, I)$

Limitation of offers and partnerships for the reverse logistics ( $D, I)$

Low availability of information about the byproducts (W, I)

Low information and underdeveloped online sales systems (W, I)

Reduction of personal, historical and emotional links with the products (W, I)

Lack of the CE indicators (D, W, I)

\section{OPPORTUNITIES}

Success stories and enhancement of the CE public policies (D, W, I)

Benchmarking with other countries (D, W)

New business models and growth of $B$ companies $(W, I)$

The European Union action plan for the CE (D, W, I)

Financing programs for innovation like Horizon 2020 (D, W)

Expansion of scientific researches linked to the CE (W, I)

Articulation for the promotion of national companies in the external market (W, I)

Prizes and international funds for innovation projects in Europe (D, W, I)

THREATS

Dependence on the importation of inputs and energy (D, W, I)

Necessity of conformity with the international market rules (W, I)

Not yet strengthened concepts adopted in some countries $(\mathrm{D}, \mathrm{W})$

International influence of products and materials with low quality and lower cost (W, I)

Economic flotation and price volatility (W, I)

Few projects and partnerships with other environmentally biased countries (W, I))

Figure 1. SWOT analysis for the dynamization of the circular economy in Portugal

Key Consolidate information in: (D) - Document and media/ (W) - Workshops/ (I) - Interviews 
Besides the influence of B Companies, the ones that aim at sustainable business systems, the negotiations in the international market are also seen as opportunity offers of more sustainable products, considering the biggest requirements of socio-environmental nature for transactions in the international market. In the furniture sector for example, characteristics linked to design, certifications and durability, besides the price, were cited in the interviews as determinant ones for the sales. The articulation of companies in cooperatives and associations strengthens the actions in this context, mainly when it is related to the SMEs [16].

Add to this the possibility of benchmarking with other countries like Holland, Scotland, Luxemburg, Denmark and Finland, which have adopted strategies, schedules and national action plans to accelerate the transition to a CE [18]. Europe, as well as China, is a precursor of actions aimed at the CE [3,13,43,44,45], with policies, media articles and academic publications following a bigger approach to residues, natural resources and business opportunities [3].

Besides the benchmarking efforts, the interviews pointed out that Portugal still has few projects and partnerships with other countries considering the environmental bias. Among the external threats to the dynamization of the CE in Portugal, it is the dependency on the importation of inputs and energy, related mainly to fossil fuels, which represent more than $70 \%$ of what is imported [18]. The need to develop materials and technology aimed at renewable sources, with the sustainable exploitation of raw materials that are essential to the economy of the country, becomes evident [17].

The competition with international markets, like the Asian one, also brings impacts when introducing materials and products with lower cost, low quality and durability into the system, going against the ecodesign and circularity concepts. The reduction of the historical and emotional links with the products, fact cited by design experts in interviews, results in a growing acceleration of global production and consumption. In contrast, during the past two decades, there has also been a growing concern of the consumers towards the acquisition of ethical products, related to fair trade and ecological footprint [46].

The CE strategies need a further discussion about policies and tools for the alignment with the international market rules, to strengthen the concepts and adoption by part of the countries in an economic block. The economic flotation and respective price volatility are also seen as a threat towards the CE, due to investment stability and paradigm shifts. Tourism, which has become a growing sector in Portugal, is an example of this condition, where the periods of recession determine flow contractions, while the economic expansions reflect on the persistent growth of tourists [47]. However, economic instability situations can also have a bias that provide opportunities for innovations and circularity of products, associated with consumption retention.

The SWOT matrix is guided by the ideal to maximize the strengths and opportunities, transform the weaknesses into strong points and reduce the threats [48].

\section{Panoramic for Brazil}

The actions, policies and scientific publications that are related to the CE on a national level in Brazil are still restrict [16]. In general, there is an environmental approach in a more corrective way, like the National Policy on Solid Residues, Law 12.305/2010, aimed at the integrated management and residue management [49]. For a benchmarking in the way that has been followed by other countries, like Portugal, including the future researches aimed at a national action plan, it is firstly necessary to identify the context and the inprogress actions that present relation with the $\mathrm{CE}$, so the theory can associate with the practice in face of the context and diagnosed opportunities.

In 2017, two publications stand out because of the aggregation of works from stakeholders seeking to increase the CE approach in Brazil and identify new business opportunities. The first one is entitled "Economia circular Holanda - Brasil: da teoria à prática" (Holand-Brazil circular economy - from theory to practice) [28], permeating a series of debates organized by the Consulate General of Netherlands in Rio de Janeiro in the year of 2016, and also with the support of the Industry Federation of the State of Rio de Janeiro, for the enhancement of discussions. The document presents reflections on the Dutch experience with the $\mathrm{CE}$, besides approaching the knowledge exchange between the countries and bringing views from the Brazilian stakeholders referent to the national context and the need for collaboration and co-creation in the search of more circular systems [28].

The other publication by the Ellen MacArthur Foundation is entitled "A circular economy in Brazil: an initial exploration", elaborated through the Circular Economy 100 program (CE100), referring to an innovation and collaboration program among companies, governments, educational institutions and organizations affiliated with the Foundation [11]. Such study concentrates on three sectors seen as important for the 
Brazilian economy: agriculture and biodiversity assets, buildings and the construction sector and electrical and electronic equipment [11]. The exploratory research from EMF, besides its range limitations, seek through actions that have already been performed, to firstly identify the CE principles and barriers in important economic activities for the country, and then seek expansion opportunities and propose future works. Such strategy was also adopted to a lesser extent for actions in the furniture sector [16].

Furthermore, there are scientific references, specifically for the CE in Brazil in the contexts of energy acquisition through residues [50,51], residue management [52,53,54], industrial symbiosis [55], trends for a circular system [9] and natural resource footprint [56]. The actions approached in these recent researches, although diffuse, contribute to a bigger approach to the CE strategies, also demonstrating the need for sectoral analyses in a country with big dimensions, along with policies that present systemic, proactive and interdisciplinary principles and goals.

Since it is an ample theme, the Portuguese experiences, through the integration of ministries and the engagement of the public power with educational institutions and society, prove to be fundamental, like a mirror for the consolidation of an integrated planning, followed by the presentation and sectoral discussion with the stakeholders, through workshops, conferences, public consultation, among others.

The weaknesses for the CE in Brazil would be, to a great extent, aligned with the results found for Portugal, since they are associated with a further dynamization of the theme. Besides the fact that, internationally, Brazil is at the top of many rankings of biodiversity richness [57], there are many challenges to face, mainly of bureaucratic and legislative nature from public management institutions [58], and a better comprehension of potential barriers to corporate environmental management [57]. With this focus, the implementation of environmental management policies also needs input provided by solid technical studies [59], through technologies that consider the technical and biological cycles.

In the international scenario, there are increasingly partnership and investment opportunities for sustainable development projects in countries with emerging economy, like the BRICS group: Brazil, Russia, India, China and South Africa [60], which needs to reduce the pressure on vulnerable natural ecosystems through projects of environmental nature, like the ones propagated by the CE [56].

\section{CONCLUSION}

When presenting the results referring to the dynamization and challenges for the CE in Portugal, this research transited through different data sources, economic sectors and stakeholders, a fact that demonstrates the dimension and complexity of the approach to this theme at a national level and in international discussions. Thus, besides the weaknesses and threats, there is a sense of maturity in the country when taking the initiative to implement an action plan and provide means of discussion for an effective contribution from society.

The strengths and opportunities listed in this research show the necessity for the recognition of the inprogress actions, besides the integration of stakeholders aiming to strengthen new work fronts. Being more and more consolidated in Europe, the CE has stood out in the political and academic areas, by even opening fields for government partnerships from different countries, which focus on researches, innovation and exchange of knowledge.

The research methodology had the numeric restriction of economic sectors involved in workshops as a limiting factor. However, as the goal of the research is linked to a national context of the dynamization of the CE in Portugal, this study did not deepen into the specificities of the involved sectors, being it a target for future researches, as well as the consolidation of indicators for a diagnosis of the planned actions in the country.

Besides the academic nature, this research also aims to contribute with benchmarking and perceptions for the formulation of strategies aimed at the CE in Brazil, mainly for policies associated with a national action plan. As in Portugal, revisions of legislation are necessary, aiming to strengthen preventive management in face of environmental aspects and foment industrial symbiosis actions, increasing the circularity of byproducts. In a country with a big territorial extension, high biodiversity and different cultures and socioeconomic conditions like Brazil, the CE needs interdisciplinary and cooperative works, which value endogenous knowledge and circular business models, supported by extensive researches on sectoral needs. The identified actions in Portugal demonstrate the importance of entrepreneurial and community partnerships, by also involving the articulation of ministries, educational institutions and society.

As contributions to a bigger approach of the CE in Brazil, research fields for future studies that contemplate sectoral diagnoses in the economy, the capture of opportunities associated with the CE and the 
consolidation of the integration models in the country are suggested, seeking a structured system for the diffusion and adoption of the circularity principles in the economy.

Funding: This study was financed in part by the Coordenação de Aperfeiçoamento de Pessoal de Nível Superior Brasil (CAPES) - Finance Code 001.Process number: 8881.131605/2016-01

Acknowledgments: The first author thanks the support of the Center for Environmental and Sustainability Research NOVA School of Science and Technology. CENSE is financed by Fundação para a Ciência e Tecnologia, I.P., Portugal (UID/AMB/04085/2019).

Conflicts of Interest: The authors declare no conflict of interest.

\section{REFERENCES}

1. European Commission. Roadmap to a resource efficient Europe. COM (2011) 571 final. Brussels: European Commission. $2011 \quad$ [cited 2017 Apr 3 3] Available from: http://www.europarl.europa.eu/meetdocs/2009_2014/documents/com/com_com(2011)0571_/com_com(2011)057 1_en.pdf

2. Gregson N, Crang M, Fuller S, Holmes H. Interrogating the circular economy: the moral economy of resource recovery in the EU. Economy and Society. 2015; 44(2): 218-243. doi:10.1080/03085147.2015.1013353

3. McDowall W, Geng Y, Huang B, Barteková E, Bleischwitz R, Türkeli S, Kemp R, Doménech T. Circular Economy Policies in China and Europe. Journal of Industrial Ecology. 2017; 21:651-661. doi:10.1111/jiec.12597

4. European Commission. Closing the loop - An EU action plan for the Circular Economy. 2015 [cited 2017 Mar 4]. Available from: http://eur-lex.europa.eu/legalcontent/ EN/TXT/PDF/?uri=CELEX:52015DC0614\&from=EN

5. Ribic B, Voca N, llakovac B. Concept of sustainable waste management in the city of Zagreb: Towards the implementation of circular economy approach. Journal of the Air \& Waste Management Association. 2017; 67(2):241-259. doi:10.1080/10962247.2016.1229700

6. Reichel A, De Schoenmakere M, Gillabel J. Circular Economy in Europe - Developing the Knowledge Base, EEA Report No. 2/2016. Publications Office of the European Union, Luxembourg. 2016 [cited 2017 Oct 7]. Available from: http://www.eea.europa.eu/publications/circular-economy-in-europe

7. Ghisellini $P$, Cialani $C$, Ulgiati S. A review on circular economy: the expected transition to a balanced interplay of environmental and economic systems. J. Clean Prod. 2016; 114:11-32. doi:10.1016/j.jclepro.2015.09.007

8. Fischer A, Pascucci S. Institutional incentives in circular economy transition: the case of material use in the Dutch textile industry. J. Clean. Prod. 2017; 155(Part 2):17-32. doi:10.1016/j.jclepro.2016.12.038

9. Nobre GC, Tavares E. Scientific literature analysis on big data and internet of things applications on circular economy: a bibliometric study. Scientometrics. 2017; 111: 463-492. doi:10.1007/s11192-017-2281-6

10. Webster K. The Circular Economy: a Wealth of Flows. Ellen MacArthur Foundation, Isle of Wight, 2015.

11. Ellen MacArthur Foundation (EMF). A circular economy in Brazil: a initial exploration. 2017 [cited 2017 Oct 7]. Available from: https://www.ellenmacarthurfoundation.org/assets/downloads/A-Circular-Economy-in-Brazil-Aninitial-exploration.pdf/

12. Bakker C, Wang F, Huisman J, Den Hollander, M. Products that go round: Exploring product life extension through design. J. Clean. Prod. 2014; 69:10-16. doi:10.1016/j.jclepro.2014.01.028

13. Bocken NMP, Pauw I, Bakker C, Van der Grinten B. Product design and business model strategies for a circular economy. J. of Industrial and Production Engineering. 2016; 33 (5):308-320. doi:10.1080/21681015.2016.1172124

14. Geissdoerfer M, Savaget P, Bocken, NMP, Hultink EJ. The Circular Economy - A new sustainability paradigm? J. Clean. Prod. 2017; 143:757-768. doi:10.1016/j.jclepro.2016.12.048

15. Ghani MA, Egilmez G, Kucukvar M, Khurrum M, Bhutta S. From green buildings to green supply chains: An integrated input-output life cycle assessment and optimization framework for carbon footprint reduction policy making", Management of Environmental Quality: An International Journal. 2017; 28 (4):532-548, doi: 10.1108/MEQ12-2015-0211

16. Oliveira FR, França SLB, Rangel LAD. Challenges and Opportunities for Circular Economy in a Furniture Local Productive Arrangement in Brazil. Resources, Conservation and Recycling. 2018; 135:202-209, doi: 10.1016/j.resconrec.2017.10.031

17. FCT (Fundação Para e Ciência e a Tecnologia), Agência Nacional de Inovação (ANI), Gabinete do Ministro da Ciência, Tecnologia e Ensino Superior (MCTES). Plano Nacional de Ciência e Tecnologia, 2017-2020. Termos de referência iniciais: para discussão. 2017; 85p.

18. IGCE (Inter-ministerial Group for Circular Economy). Leading the Transition: Action Plan for Circular Economy in Portugal 2017-2020. 2017 [cited 2017 Jun 6].; 62p. Available from: http://185.32.37.73/contents/ficheiros/paec-enversion-3.pdf 
19. ECO.NOMIA (Circular Economy Portal). Portuguese Republic - Ministry of the Environment. 2017 [cited 2017 Mar 5]. Available from: http://eco.nomia.pt/

20. BCDS Portugal (Business Council for Sustainable Development). Circular economy. 2017 [cited 2017 Apr 18]. Available from: http://www.bcsdportugal.org/areas-de-atividade/economia-circular

21. Fellows R, Liu A. Research methods for construction. 2008. 3rd ed, Chichester, WileyBlackwell.

22. Beverland M, Lindgreen A. What makes a good case study? A positivist review of qualitative case research published in Industrial Marketing Management, 1971-2006. Industrial Marketing Management. 2010; 39:56-63. doi:10.1016/j.indmarman.2008.09.005

23. Gibbert M, Ruigrok W. The What and How of Case Study Rigor: Three strategies based on Published Work. Organizational Research Methods. 2010; 13(4):710-737. doi:10.1177/1094428109351319

24. Ruparathna R, Hewage K. Sustainable procurement in the Canadian construction industry: current practices, drivers and opportunities. J. Clean. Prod. 2015; 109:305-314. doi: 10.1016/j.jclepro.2015.07.007

25. Uittenbroek CJ, Janssen-Jansen LB, Runhaar HAC. Stimuli for climate adaptation in cities: insights from Philadelphia - an early adapter. International Journal of Climate Change Strategies and Management. 2016; 8(1):38-56. doi:10.1108/IJCCSM-06-2014-0069

26. Creswell JW. Research design: Qualitative, quantitative and mixed methods approaches (4th ed.). Thousand Oaks, CA, Sage, 2014.

27. Gao X, Chen L, Sun B, Liu Y. Employing SWOT Analysis and Normal Cloud Model for Water Resource Sustainable Utilization Assessment and Strategy Development. Sustainability. 2017; 9 (8):1439. doi:10.3390/su9081439

28. Luz B (Org.). Economia circular Holanda - Brasil: da teoria à prática. 1. ed. Rio de Janeiro: Exchange 4 Change Brasil, 2017 [cited 2017 Aug 29]. 164p. Available from: <http://www.firjan.com.br/publicacoes/manuais-ecartilhas/economia-circular-holanda-brasil-da-teoria-a-pratica.htm>

29. Delgado C. Agricultura urbana, espaço de protagonismo feminino: dinâmicas e potencialidades. Faces de Eva Estudos sobre a mulher. 2017 [cited 2017 Jun 28]; 37:63-81. Available from: http://www.scielo.mec.pt/scielo.php?script=sci_abstract\&pid=S087468852017000100006\&lng=pt\&nrm=iso\&tlng=en

30. Breure AM, Lijzen JPA, Maring L. Soil and land management in a circular economy. Science of The Total Environment. 2018; 624:1125-1130. doi:10.1016/j.scitotenv.2017.12.137

31. Garcia-Herrero I, Margallo M, Onandía R, Adalco R, Irabien A. Connecting wastes to resources for clean technologies in the chlor-alkali industry: a life cycle approach. Clean Techn Environ Policy. 2018; 20: 229. doi:10.1007/s10098-017-1397-y

32. Huysman S, De Schaepmeester J, Ragaert K, Dewulf J, De Meester S. Performance indicators for a circular economy: A case study on post-industrial plastic waste. Resources, Conservation and Recycling. 2017; 120: $46-$ 54. doi:10.1016/j.resconrec.2017.01.013

33. Smol M, Kulczycka J, Avdiushchenko A. Circular economy indicators in relation to eco-innovation in European regions. Clean. Techn. Environ. Policy. 2017; 19(3):669 - 678. doi:10.1007/s10098-016-1323-8.

34. Molina-Moreno V, Leyva-Díaz JC, Llorens-Montes FJ, Cortés-García FJ. Design of Indicators of Circular Economy as Instruments for the Evaluation of Sustainability and Efficiency in Wastewater from Pig Farming Industry. Water; 2017; 9(9): 653. doi:10.3390/w9090653

35. Haupt M, Vadenbo C, Hellweg S. Do We Have the Right Performance Indicators for the Circular Economy? Insight into the Swiss Waste Management System. Journal of Industrial Ecology. 2017; 21:615-627. doi:10.1111/jiec.12506

36. Rizos V, Behrens A, Van der Gaast W, Hofman E, loannou A, Kafyeke T, Flamos A, Rinaldi, R, Papadelis S, Hirschnitz-Garbers M, Topi C. Implementation of Circular Economy Business Models by Small and Medium-Sized Enterprises (SMEs): Barriers and Enablers. Sustainability. 2016; 8(11): 1212. doi: 10.3390/su8111212

37. Winans K, Kendall A, Deng H. The history and current applications of the circular economy concept. Renew. Sust. Energ. Rev. 2017; 68(Part 1): 825-833. doi:10.1016/j.rser.2016.09.123.

38. UNEP - United Nations Environment Programme. Summary for Policy Makers of the IRP report for the G7. Resource efficiency: potential and economic implications. International Resource Panel. Paris, France: UN Environment; 2016.

39. Tecchio P, McAlister C, Mathieux F, Ardente F. In search of standards to support circularity in product policies: A systematic approach. J. Clean. Prod. 2017; 168:1533-1546. doi:10.1016/j.jclepro.2017.05.198

40. De Man R, Friege H. Circular economy: European policy on shaky ground. Waste Management and Research. 2016; 34 (2):93-95. doi:10.1177/0734242X15626015

41. Pollex J, Lenschow A. Surrendering to growth? The European Union's goals for research and technology in the Horizon 2020 framework. J. Clean. Prod. 2016. doi:10.1016/j.jclepro.2016.10.195 
42. Ellen MacArthur Foundation (EMF). Growth within: a Circular Economy Vision for a Competitive Europe. 2015 [cited 2017 Oct 10]. Available from: https://www.ellenmacarthurfoundation.org/publications/growth-within-a-circulareconomy-vision-for-a-competitive-europe

43. Naustdalslid J. Circular economy in China - the environmental dimension of the harmonious society, International Journal of Sustainable Development \& World Ecology. 2014; 21(4): 303-313. doi:10.1080/13504509.2014.914599

44. Mathews JA, Tan H. Progress toward a circular economy in China: The drivers (and inhibitors) of eco-industrial initiative. Journal of Industrial Ecology. 2011; 15:435-457. doi:10.1111/j.1530-9290.2011.00332.x.

45. Geng Y, Doberstein B. Developing the circular economy in China: Challenges and opportunities for achieving 'leapfrog development', International Journal of Sustainable Development \& World Ecology. 2010; 15(3): 231-239. doi:10.3843/SusDev.15.3:6

46. Ladhari R, Tchetgna NM. Values, socially conscious behaviour and consumption emotions as predictors of Canadians' intent to buy fair trade products. International Journal of Consumier Studies. 2017; 41: 696-705. doi:10.1111/ijcs.12382.

47. Andraz, JM, Rodrigues, PMM. Monitoring tourism flows and destination management: Empirical evidence for Portugal. Tourism Management. 2016; 56:1-7. doi:10.1016/j.tourman.2016.03.019

48. Yuan H. A SWOT analysis of successful construction waste management. J. Clean. Prod. 2013; 39:1-8. doi:10.1016/j.jclepro.2012.08.016

49. Colling AV, Oliveira LB, Reis MM, Cruz NT, Hunt JD. Brazilian recycling potential: energy consumption and Green House Gases reduction. Renewable and Sustainable Energy Reviews. 2016; 59:544-549. doi:10.1016/j.rser.2015.12.233

50. Ribeiro EM, Barros RM, Tiago Filho GL, Santos IFS, Sampaio LC, Santos TV, Silva FGB, Silva APM, Freitas JVR. Power generation potential in posture aviaries in Brazil in the context of a circular economy. Sustainable Energy Technologies and Assessments. 2016;18:153-163. doi:10.1016/j.seta.2016.10.009.

51. Sánchez AS, Silva YL, Kalid RA, Cohim E, Torres EA. Waste bio-refineries for the cassava starch industry: New trends and review of alternatives. Renewable and Sustainable Energy Reviews. 2017; 73:1265-1275. doi:10.1016/j.rser.2017.02.007

52. Polzer VR, Pisani MAJ, Persson KM. The importance of Extended Producer Responsibility and the National Policy of Solid Waste in Brazil. International Journal of Environment and Waste Management. 2016; 18(2):109-119. doi:10.1504/IJEWM.2016.080398

53. Velis C. Waste pickers in Global South: Informal recycling sector in a circular economy era. Waste Management \& Research. 2017; 35(4):329-331. doi:10.1177/0734242X17702024

54. Andrade Junior M, Zanghelini G, Soares S. Using life cycle assessment to address stakeholders' potential for improving municipal solid waste management. Waste Management and Research. 2017; 35 (5):541-550, doi:10.1177/0734242X17697817

55. Ceglia D, Abreu M, Silva Filho J. Critical elements for eco-retrofitting a conventional industrial park: Social barriers to be overcome. Journal of Environmental Management. 2017; 187:375-383. doi:10.1016/j.jenvman.2016.10.064

56. Wu R, Geng Y, Liu W. Trends of natural resource footprints in the BRIC (Brazil, Russia, India and China) countries. J. Clean. Prod. 2017; 142(Part 2):775-782. doi:10.1016/j.jclepro.2016.03.130.

57. Jabbour CJC, Jugend D, Jabbour ABLDS, Govindan K, Kannan D, Leal Filho W. "There is no carnival without samba": Revealing barriers hampering biodiversity-based R\&D and eco-design in Brazil. Journal of Environmental Management. 2018; 206 (15): 236-245. doi:10.1016/j.jenvman.2017.10.019

58. Pedrollo CT, Kinupp VF. Sustainability or colonialism? Legislative obstacles to research and development of natural products and patents on traditional knowledge in Brazil. Acta Bot. Bras. 2015; 29 (3): 452-456. doi:10.1590/0102$33062015 a b b 0101$

59. Oliveira MC, Magrini A. Life cycle assessment of lubricant oil plastic containers in Brazil. Sustainability. 2017; 9(4): 576. doi: $10.3390 /$ su9040576

60. Ahmed, K. Revisiting the role of financial development for energy-growth-trade nexus in BRICS economies. Energy. 2017; 128:487-495. doi:10.1016/j.energy.2017.04.055

2020 by the authors. Submitted for possible open access publication under the terms and conditions of the Creative Commons Attribution (CC BY NC) license (https://creativecommons.org/licenses/by-nc/4.0/). 